\title{
Importance of non-olfactory ram stimuli in mediating ram-induced ovulation in the ewe
}

\author{
G. P. Pearce and C. M. Oldham \\ Animal Science Group, School of Agriculture, University of Western Australia, Nedlands, \\ Western Australia 6009, Australia
}

\begin{abstract}
Summary. In Exp. 1, 4 groups of 50 recently weaned ewes were exposed to various degrees of contact with rams for 65 days, followed by exposure to novel rams for 4 days. Ovarian activity in the ewes was determined by laparoscopy on Days 29, 65 and 69 of treatment. There were no treatment differences in the percentage of ewes ovulating on Day 4 whereas by Day 29 more ewes in clear fenceline and full ram contact were ovulating compared to controls $(P<0.05, P<0.001)$. After 65 days ovarian activity was significant only in those ewes in full contact with rams $(P<0.001)$. Between 89 and $95 \%$ of ewes remaining anovulatory after 65 days ovulated after 4 days of full contact with novel rams.

In Exp. 2, 4 groups of about 30 anovulatory ewes were exposed to various degrees of contact with rams for 5 days. Ovarian activity was assessed before and after treatment by laparoscopy. After 5 days, more ewes were ovulating in response to full ram contact than in any other treatment $(P<0.05)$ and more ewes in fenceline contact with rams or with rams plus ewes were ovulating than in the isolated control treatment $(P<0.01)$.

In Exp. 3, 6 groups of about 40 anovulatory ewes were exposed to face masks with and without rams' wool and/or various degrees of contact with rams for 5 days. More ewes were ovulating after 5 days in the group in full physical contact with rams than in any other group $(P<0 \cdot 01)$. Ram contact through a clear fence either with or without masks stimulated more ewes to ovulate than masks alone or isolation from rams $(P<0.01)$. The additional exposure to rams' wool did not increase the percentage of ewes ovulating in response to fenceline ram contact or masks alone but exposure to masks themselves with or without rams' wool did stimulate ovulation compared to isolated controls ( $P<0.05, P<0.01$ respectively).

These results indicate that fenceline ram contact was effective in inducing ovulation in a high proportion of seasonally anovulatory ewes but less effective in lactationally anovulatory ewes. Furthermore, maximum stimulation of ovulation required full physical contact with rams in all cases. Visual and tactile/behavioural stimuli from the ram therefore appear most important in mediating the ram effect whereas olfactory cues from Merino rams' wool were ineffective either alone or in addition to fenceline ram exposure. Pre-isolation of ewes from rams was not required when novel rams were used to induce subsequent ovulation.
\end{abstract}

Keywords: ram stimuli; induced ovulation; ewes

\section{Introduction}

Exposure to rams has been widely reported to advance the onset of the breeding season in many breeds of ewe and this phenomenon, known as the "ram effect", has been the subject of several 
recent reviews (e.g. Knight, 1983; Pearce \& Oldham, 1984; Martin et al., 1986). Although the underlying endocrine mechanism of the ram effect is now well understood (Martin et al., 1986), the proportion of anovulatory ewes responding to ram contact remains variable between flocks, between breeds and from year to year within the same flock (Knight, 1983; Martin, 1984). At least part of this variability may be due to variations in the degree of stimulation presented by the rams in the different circumstances used in individual experiments. Many aspects of the conditions required to maximize the ewe's response to ram contact remain unclear. For example, early work suggested that ewes would only respond to the introduction of rams if they had been preconditioned by a period of isolation (Underwood et al., 1944; Schinckel, 1954), yet the exact nature of this isolation is still unknown and it is not clear whether the ewes become habituated to particular rams and whether the subsequent introduction of novel rams remains stimulatory.

Extensive studies of the mechanism of the ram effect have led to the suggestion that it is primarily a response to pheromones present in the wool of rams (Watson \& Radford, 1960; Morgan et al., 1972; Knight \& Lynch, 1980a, b; Knight et al., 1983). However, more recent studies have questioned whether the ram effect is mediated solely by pheromones (reviewed in Martin et al., 1986) and non-olfactory ram stimuli have been implicated. The variability in response observed in previous work may have been at least partly due to variability in the presentation of non-olfactory cues, previously considered to be unimportant, from the rams.

The objectives of the present studies were (1) to define which ram stimuli are involved in mediating a maximum ovulatory response in anovulatory ewes, and (2) to investigate the nature of the apparent habituation of ewes to the continual presence of rams.

\section{Materials and Methods}

Experiment 1. Multiparous Merino ewes from the Martindale Research Farm (Newdale) were weaned at $12 \pm 6$ weeks post partum and randomly allocated to the following treatments in 3 ha paddocks in early September 1986; Group $1(\mathrm{~N}=50)$, complete isolation from rams (by $1.5 \mathrm{~km}$ with no possible visual contact); Group $2(\mathrm{~N}=50)$, exposure to contact with 6 rams through an opaque fence; Group $3(\mathrm{~N}=50)$, exposure to contact with 6 rams through a clear fence; Group $4(\mathrm{~N}=50)$, exposure to contact with 6 rams in the same paddock. The opaque fence used for Group 2 consisted of a 6-strand plain wire fence $1.2 \mathrm{~m}$ high, completely covered with heavy duty black plastic. The clear fences consisted of plain wire only. All rams used to provide full contact in the same paddock were vasectomized in early August 1986 and checked for the production of motile spermatozoa by electroejaculation before use.

The treatments were maintained for 65 days until early November 1986. To establish the degree of ovulatory activity, the ovaries of the ewes were examined by laparoscopy using the method of Oldham et al. (1976) after 4, 29 and 65 days of treatment. After laparoscopy on Day 65 the 4 groups of ewes were combined and exposed to contact with 12 novel vasectomized rams. These novel rams had previously been running with a flock of spontaneously ovulating ewes for 65 days, but had not been in contact with the experimental ewes before this time. After 4 days of full contact with the novel rams, the ewes were again investigated laparoscopically to assess the ovulatory response.

Experiment 2. Multiparous non-pregnant Merino ewes were obtained from the same flock as the ewes used in Exp. 1 and subjected to laparoscopy in mid-November 1987. These ewes had been isolated from rams for at least 6 months before laparoscopy. Those ewes considered to be acyclic as defined by Oldham \& Lindsay (1980) (i.e. having no corpora lutea, corpora albicantia or corpora haemorrhagica visible on the ovarian surface) were randomly allocated to the following treatments in 5 ha paddocks: Group $1(\mathrm{~N}=31)$, complete isolation from rams; Group $2(\mathrm{~N}=33)$, exposure to contact with 5 rams only through a clear fence; Group $3(N=31)$, exposure to contact with 5 rams running with ewes through a clear fence; Group $4(N=30)$, exposure to full contact with 5 rams in the same paddock. After 5 days of treatment the ewes were again investigated laparoscopically to assess the occurrence of ovulation.

Experiment 3. Multiparous Merino ewes from the University of Western Australia Research Farm (Allandale) were randomly selected from a flock of non-pregnant ewes in late September 1987 and subjected to laparoscopy. These ewes had been isolated from rams for at least 6 months before laparoscopy. Ewes considered to be acyclic (as defined above) were randomly allocated to the following treatments in 2 ha paddocks: Group $1(\mathrm{~N}=43)$, complete isolation from rams; Group $2(\mathrm{~N}=20)$, exposure to empty face masks; Group $3(\mathrm{~N}=40)$, exposure to rams' wool in face masks; Group $4(N=40)$, exposure to contact with 5 rams through a clear fence; Group $5(N=39)$, exposure to rams' wool in face masks plus contact with 5 rams through a clear fence; Group $6(\mathrm{~N}=37)$, exposure to full contact with 5 rams in the same paddock.

The masks used in Groups 2, 3 and 5 were based on those developed by Knight et al. (1983) and consisted of a modified 250-ml sample jar (Bunzl Ltd, Seaton, South Australia) with a perforated base and lid held close under the 
ewes' muzzle by a canvas bag tied behind the ears. The masks were fitted for $20 \mathrm{~h}$ per day for 4 days, being removed for $4 \mathrm{~h}$ each day to allow the ewes access to pasture and water. The jars in masks used in Groups 3 and 5 were loosely filled each day with freshly shorn wool (about $5 \mathrm{~cm}$ in length, stored in sealed plastic bags and used within 5 days of shearing) from pure bred Merino rams. Wool from a different mature ram was used each day. On the 5th day of treatment, all ewes were again subjected to laparoscopy to assess the effect of treatment on the occurrence of ovulation.

Statistical analysis. Treatment differences in the proportions of ewes ovulating were assessed using the Fisher exact probability test.

\section{Results}

\section{Experiment 1}

The ovulatory responses of the ewes to the various degrees of ram contact are shown in Table 1. There was no difference in the number of ewes ovulating after 4 days in any of the treatments. After 29 days of treatment more ewes in Groups $3(P<0.05)$ and $4(P<0.001)$ were ovulating compared to Group 1 (isolated controls) and more ewes in Group 4 were ovulating than in Group 3 $(P<0.05)$. After 65 days of treatment, ovarian activity was significant only in ewes in Group 4 and only in Group 4 did the number of ovulatory ewes increase with increasing duration of ram contact $(P<0.01)$. Contact with rams through opaque or clear fences for 65 days (Groups 2 and 3 ) did not increase the number of ewes ovulating compared to isolated control ewes (Group 1). Between 89 and $95 \%$ of ewes remaining anovulatory after 65 days of treatment were induced to ovulate by 4 days of full ram contact with novel rams (Table 1).

Table 1. The importance of visual and tactile cues and of novelty of rams in mediating the ram-effect (Exp. 1)

\begin{tabular}{|c|c|c|c|c|c|}
\hline \multirow[b]{2}{*}{ Group } & \multirow[b]{2}{*}{ Treatment } & \multicolumn{3}{|c|}{$\%$ of ewes ovulating after } & \multirow{2}{*}{$\begin{array}{l}\% \text { of anovulatory ewes } \\
\text { ovulating after } 4 \text { days } \\
\text { of novel ram contact }\end{array}$} \\
\hline & & 4 days* & 29 days* & 65 days & \\
\hline 1 & $\begin{array}{l}\text { No contact with } \\
\text { rams }\end{array}$ & $\begin{array}{c}4 \\
(1 / 24)\end{array}$ & $\begin{array}{c}8^{x} \\
(2 / 25)\end{array}$ & $\begin{array}{c}4^{b x} \\
(2 / 47)\end{array}$ & $\begin{array}{c}91^{c} \\
(41 / 45)\end{array}$ \\
\hline 2 & $\begin{array}{l}\text { Opaque fenceline } \\
\text { contact with rams }\end{array}$ & $\begin{array}{c}4 \\
(1 / 25)\end{array}$ & $\begin{array}{c}11^{x y} \\
(5 / 46)\end{array}$ & $\begin{array}{c}12^{\mathrm{b}} \\
(6 / 49)\end{array}$ & $\begin{array}{c}95^{\mathrm{c}} \\
(41 / 43)\end{array}$ \\
\hline 3 & $\begin{array}{l}\text { Clear fenceline } \\
\text { contact with rams }\end{array}$ & $\begin{array}{c}4^{\mathrm{a}} \\
(1 / 24)\end{array}$ & $\begin{array}{l}22^{\text {by }} \\
(9 / 40)\end{array}$ & $\begin{array}{c}4^{a} \\
(2 / 48)\end{array}$ & $\begin{array}{c}89^{c} \\
(41 / 46)\end{array}$ \\
\hline 4 & $\begin{array}{l}\text { Full physical } \\
\text { contact with rams }\end{array}$ & $\begin{array}{c}4^{a} \\
(1 / 23)\end{array}$ & $\begin{array}{r}49^{\mathrm{bz}} \\
(21 / 43)\end{array}$ & $\begin{array}{c}78^{\mathrm{cy}} \\
(36 / 46)\end{array}$ & $\begin{array}{l}90 \\
(9 / 10)\end{array}$ \\
\hline
\end{tabular}

*Not all ewes were subjected to laparoscopy in every treatment on these dates.

a,b,c: Values within each row are significantly different $(P<0 \cdot 05)$.

$\mathrm{x}, \mathrm{y}, \mathrm{z}$ : Values within each column are significantly different $(P<0.05)$.

\section{Experiment 2}

Full contact with rams in the same paddock for 5 days (Group 4) induced ovulation in 29/30 $(97 \%)$ of previously anovulatory ewes $(P<0.05$ compared with the other three groups). Clear fenceline contact with rams and ewes (Group 3) or with rams alone (Group 2) induced ovulation in a significant proportion $(P<0.01)$ of ewes $(19 / 31(61 \%)$ and $15 / 33(45 \%)$ respectively) compared to isolated control animals (Group 1) $(4 / 31(13 \%))$ but this was less than the proportion ovulating in response to full contact with rams $(P<0.001)$. There was no significant difference in the proportion of ewes ovulating in Groups 2 and 3. 


\section{Experiment 3}

The proportions of ewes ovulating after 5 days of treatment are shown in Fig. 1.

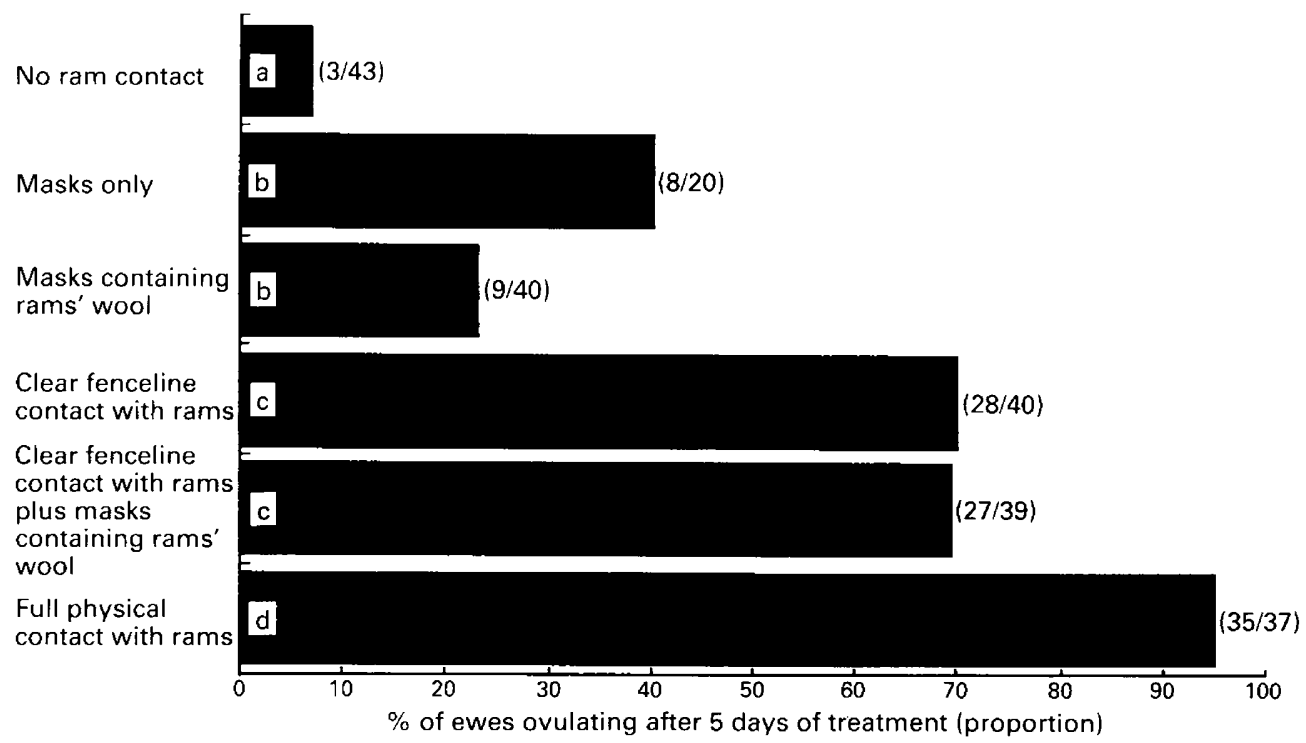

Fig. 1. The importance of contact, visual and olfactory ram stimuli in inducing ovulation in anovulatory ewes (Exp. 3). Values with different letters are significantly different (at least $P<0 \cdot 05)$.

\section{Discussion}

The proportion of ewes ovulating in response to ram exposure was significantly greater in all three experiments in this study when physical contact with the rams in the same paddock was allowed. Therefore although olfactory cues from rams have been reported to be important in mediating the ram effect (Knight et al., 1983), the results of the present series of experiments clearly show that other cues from the male are also involved. Indeed, the proportion of ewes ovulating was increased by both the tactile/behavioural cues presented by physical contact with rams and by the visual cues provided by rams running alone or with ewes.

Physical contact between the sexes has been shown to be necessary for the maximum efficacy of many reproductive phenomena in mammals which were previously thought to be mediated by pheromones alone. Physical contact is a prerequisite for the influence of the male on oestrous cyclicity and ovulation in bank voles (Clarke \& Hellwing, 1977), wild guinea-pigs (Weir, 1971) and rats (Johns et al., 1978), implantation failure in voles (Milligan, 1980) and mice (Rajendren \& Dominic, 1984), lordosis block in hamsters (Brown \& Lisk, 1978) and the effects of females on oestrous cyclicity in mice (Gandrade \& Dominic, 1981, 1984). In addition, tactile cues presented by physical contact with males act synergistically with pheromones in male-induced precocious puberty in female pigs (Pearce \& Hughes, 1987a) and mice (Drickamer, 1974; Bronson \& Maruniak, 1975). Similarly, it has been reported that the proportion of seasonally anovulatory female goats ovulating in response to male exposure was significantly increased when physical contact was allowed (Shelton, 1980). In view of this volume of evidence it is perhaps not surprising that physical contact with rams was observed to maximize the efficacy of ram-induced ovulation in the present study, indicating that the ram effect is not simply a response to male pheromones as had been suggested previously (Knight, 1983). 
The importance of physical contact with rams may lie in the provision of tactile cues from the male. The involvement of tactile cues from the ram has been suggested by the work of Edgar \& Bilkey (1963) in which the efficacy of the ram effect was reduced when rams of lower libido were used such that the number of physical encounters between the sexes was reduced. Signoret et al. (1982) also observed that the induction of ovulation was more effective with males of high sexual activity compared to inactive males. Acute stressors such as transportation have been reported to stimulate ovulation in ewes (Lang, 1964; Braden \& Moule, 1964) and it is possible that physical contact with rams contains a stress component which is involved in stimulating ovulation as has been suggested to occur in the boar-effect (Pearce \& Hughes, 1987b; Pearce et al., 1988). In the present Exp. 3 the stress involved in wearing the masks stimulated ovulation in a significant proportion of ewes. The stimulatory effect of masks per se disagrees with the findings of Knight et al. (1983) who observed no effect of the masks themselves on ovulation in Romney ewes. However, full ram contact in their study induced ovulation in only $47 \%$ of ewes compared to $95 \%$ in Exp. 3 .

Alternatively, contact may be required for the transfer of the pheromones involved in the ram effect (Knight \& Lynch, 1980a, b). Certain mammalian pheromones previously thought to be volatile and air-borne are now known to be perceived by recipients through close contact with the source (e.g. Rajendren \& Dominic, 1984). The use of rams' wool in face masks in Exp. 3 was designed to test whether the importance of contact was in fact due to the direct transfer of pheromones from the ram's fleece to the ewe. However, no more ewes ovulated in response to masks containing wool than to masks alone, nor did the addition of wool to the masks increase the proportion of ewes ovulating in response to fenceline ram contact. The reason for this ineffectiveness of rams' wool is unclear in view of the previous reports that exposure to rams' wool induced ovulation in $37-70 \%$ of ewes (Knight \& Lynch, 1980b) and increased LH secretion in $68 \%$ of treated ewes (Signoret \& Lindsay, 1982). These authors used wool from Dorset and Romanov rams respectively. Our present results suggest that wool from mature Merino rams does not contain the putative pheromone found in the wool of rams of other breeds. The rams' wool used in the present study was collected from mature adult Merino rams either running with castrated males in paddocks or housed in metabolism crates in animal houses containing only castrated males. It is possible that these rams were not releasing pheromones into their wool because they were not in contact with females. Knight (1985) suggested that the presence of oestrous ewes stimulated rams to produce and/or release more pheromones, thereby improving the efficacy of contact with these rams in stimulating ovulation in other anovulatory ewes. Although the results of Exp. 2 showed a tendency for more ewes to be stimulated to ovulate in response to fenceline contact with ewes and rams compared to rams alone, it is not clear whether this was due to increased pheromone production by the rams or to different visual or behavioural cues being provided by the 'stimulated rams'.

Clear fenceline contact with rams (or rams plus ewes) did stimulate ovulation in a significant proportion of ewes in each of the experiments reported in this study. The ineffectiveness of opaque fenceline contact in Exp. 1 indicated that visual rather than olfactory cues from the rams were the stimulating components involved in clear fenceline contact. This suggestion is supported by the findings of Cohen-Tannoudji et al. (1986) who reported that ewes rendered anosmic by bulbectomy still responded to the introduction of rams with a normal LH response whereas rams' wool alone was ineffective. Similarly, anosmic female goats have been reported to release $\mathrm{LH}$ in response to the presence of males (Chemineau et al., 1986). This evidence, coupled with our own observations, suggests that non-olfactory sensory cues, notably vision, are intimately involved in mediating the ram effect. The role of learning and/or conditioning in eliciting the endocrine and ovulatory responses of ewes to cues from rams is largely unknown. However, Murtagh et al. (1984) reported an increased ovulatory response to rams in 15-month-old ewes which had had previous male contact compared to previously isolated females and this suggests that learning is involved in the ram effect.

The observation that $90 \%$ of those ewes remaining anovulatory after 65 days of full ram contact in Exp. 1 subsequently ovulated within 4 days of contact with novel rams questions the 
proposal that ewes need to be preconditioned by a period of pre-isolation before they will respond to the ram effect (Underwood et al., 1944; Riches \& Watson, 1954). The results of the present study would suggest that the ewes will respond if novel, previously unknown rams are used. In support of this finding is the report of MacMillan (1987) that ewes remaining anovulatory after 4 days of contact with male goats subsequently ovulated in response to contact with novel rams. It is possible that females habituate to particular males in continual contact with them, but novel males remain stimulatory as has been reported to occur in female rats (Purvis et al., 1971).

Differences were observed between the experiments of this study in the response to 'limited' ram contact through a clear fence. Whereas 5 days of clear fenceline ram contact was effective in stimulating $45-70 \%$ of ewes to ovulate in Exps 2 and 3 there was no difference between ewes in this treatment and isolated controls after 4 days in Exp. 1. This finding illustrates the fact that the efficacy of the ram effect varies greatly between different populations of ewes. The progressive increase in the proportion of ewes ovulating in response to the increasing duration of full physical contact with rams in Exp. 1 supports the suggestion by Signoret et al. (1982) that the magnitude of response to rams increases with continued ram contact. Although 29 days of clear fenceline ram contact in Exp. 1 stimulated ovulation in a significant proportion of ewes, most of these ewes had become anovulatory again after 65 days of this treatment in contrast to the progressive increase in the proportion of ewes ovulating in full contact with rams. It therefore appears from the present study that, in animals in 'deep' anoestrus (seasonal and lactational in Exp. 1), full physical contact with rams was needed to induce a sustained ovulatory response. In contrast, in those animals less 'deep' in anoestrus (seasonal only in Exps 2 and 3) exposure to the rams through a clear fence was effective in stimulating a significant proportion of ewes to ovulate within 5 days. However, in all cases full physical contact with rams induced ovulation in the greatest proportion of anovulatory ewes.

The results of the present study therefore demonstrate that the ram effect is mediated by a combination of stimuli from the ram, the most important of which may be visual and tactile cues. Olfactory cues, in the Merino breed at least, may not be as important in mediating this phenomenon as was previously thought from work using other breeds of sheep.

We thank the Australian Meat and Livestock Research and Development Corporation and the Martindale Research Project for supporting this study; P. Burton, P. Moore, T. Murphy, R. Nowak, R. Oldham, A. N. Pearce, I. G. Putu, J. Shaw, D. Suckling and J. Wilkins for valuable assistance during laparoscopies; and Dr G. B. Martin for comments on the manuscript.

\section{References}

Braden, A.W.H. \& Moule, G.W. (1964) Effects of stress on ovarian morphology and oestrous cycles in ewes. Aust. J. agric. Res. 15,937-949.

Bronson, F.H. \& Maruniak, J.A. (1975) Male-induced puberty in female mice: evidence for a synergistic action of social cues. Biol. Reprod. 13, 94-98.

Brown, S.M. \& Lisk, R.D. (1978) Blocked sexual receptivity in female golden hamsters, the result of contact induced inhibition. Biol. Reprod. 18, $829-833$.

Chemineau, P., Levy, F. \& Thimonier, J. (1986) Effects of anosmia on LH secretion, ovulation and oestrous behaviour induced by males in the anovular Creole goat. Anim. Reprod. Sci. 10, 125-132.

Clarke, J.R. \& Hellwing, S. (1977) Remote control by males of ovulation in bank voles (Clethrionomys glareolus). J. Reprod. Fert. 50, 155-158.
Cohen-Tannoudji, J., Locatelli, A. \& Signoret, J.P. (1986) Non-pheromonal stimulation by the male of $\mathbf{L H}$ release in the anoestrous ewe. Physiol. Behav. 36, 921-924.

Drickamer, L.C. (1974) Contact stimulation, androgenized females and accelerated sexual maturation in female mice. Behav. Biol. 12, 101-110.

Edgar, D.G. \& Bilkey, D.A. (1963) The influence of rams on the onset of the breeding season in ewes. Proc. N.Z. Soc. Anim. Prod. 23, $79-87$.

Gandrade, B.K. \& Dominic, C.J. (1981) Role of contact stimuli in estrous cycle irregularities in unisexually grouped mice. Indian J. exp. Biol. 19, 645-646.

Gandrade, B.K. \& Dominic, C.J. (1984) Groupinginduced disruption of estrous cycle in mice: role of physical contact and gonadal hormones. Environ. Control in Biol. 22, 63-69. 
Johns, M.A., Feder, H.H., Komisaruk, B.R. \& Mayer, A.D. (1978) Urine-induced reflex ovulation in anovulatory rats may be a vomeronasal effect. Nature. Lond. 272, 446-448.

Knight, T.W. (1983) Ram-induced stimulation of ovarian and oestrous activity in anoestrous ewes-a review. Proc. N.Z. Soc. Anim. Prod. 43, 7-11.

Knight, T.W. (1985) Are rams necessary for the stimulation of anoestrous ewes with oestrous ewes? Proc. N.Z. Soc. Anim. Prod. 45, 49-50.

Knight, T.W. \& Lynch, P.R. (1980a) Source of ram pheromones that stimulate ovulation in the ewe. Anim. Reprod. Sci. 3, 133-136.

Knight, T.W. \& Lynch, P.R. (1980b) The pheromones from rams that stimulate ovulation in the ewe. Proc. Aust. Soc. Anim. Prod. 13, 74-76.

Knight, T.W., Tervit, H.R. \& Lynch, P.R. (1983) Effect of boar pheromones, rams' wool and the presence of bucks on ovarian activity in anovular ewes early in the breeding season. Anim. Reprod. Sci. 6, 129-134.

Lang, D.R. (1964) Ovulations in Merino ewes moved by road or rail in Queensland. Proc. Aust. Soc. Anim. Prod. 5, 53-57.

McMillan, W.H. (1987) The male effect-a comparison of rams and bucks for teasing ewes. Proc. N.Z. Soc. Anim. Prod. 47, 135-137.

Martin, G.B. (1984) Factors affecting the secretion of luteinizing hormone in the ewe. Biol. Rev. 59, 1-87.

Martin, G.B., Oldham, C.M., Cognie, Y. \& Pearce, D. (1986) The physiological responses of anovulatory ewes to the introduction of rams-a review. Livest. Prod. Sci. 15, 219-247.

Milligan, S.R. (1980) Pheromones and rodent reproductive physiology. Symp. Zool. Soc. Lond. 45, 251-275.

Morgan, P.D., Arnold, G.W. \& Lindsay, D.R. (1972) A note on the mating behaviour of ewes with various senses impaired. J. Reprod. Fert. 30, 151-152.

Murtagh, J.J., Gray, S.J., Lindsay, D.R. \& Oldham, C.M. (1984) The influence of the "ram effect" in 10-11 month old Merino ewes on their subsequent performance when introduced to rams again at 15 months of age. Proc. Aust. Anim. Prod. 15, 490-493.

Oldham, C.M. \& Lindsay, D.R. (1980) Laparoscopy in the ewe: a photographic record of the ovarian activity of ewes experiencing normal or abnormal oestrous cycles. Anim. Reprod. Sci. 3, 119-124.

Oldham, C.M., Knight, T.W. \& Lindsay, D.R. (1976) A comparison of the effects on reproductive performance in sheep, of two methods of estimation of ovulation rate. Aust. J. exp. Agric. Anim. Husb. 16, 24-27.

Pearce, D.T. \& Oldham, C.M. (1984) The "ram-effect", its mechanism and application to the mariagement of sheep. In Reproduction in Sheep, pp. 26-34. Eds D. R. Lindsay \& D. T. Pearce. Australian Academy of Science, Canberra.

Pearce, G.P. \& Hughes, P.E. (1987a) The influence of boar-component stimuli on puberty attainment in the gilt. Anim. Prod. 44, 293-302.

Pearce, G.P. \& Hughes, P.E. (1987b) The influence of male contact on plasma cortisol concentrations in the prepubertal gilt. J. Reprod. Fert. 80, 417-424.

Pearce, G.P., Paterson A.M. \& Hughes, P.E. (1988) Effect of short-term elevations in plasma cortisol concentrations on $\mathrm{LH}$ secretion in prepubertal gilts. J. Reprod. Fert. 83, 413-418.

Purvis, K., Cooper, K.J. \& Haynes, N.B. (1971) The influence of male proximity and dietary restriction on the oestrous cycle of the rat. J. Reprod. Fert. 27, $167-176$.

Rajendren, G. \& Dominic, C.J. (1984) Involvement of contact stimuli in the male-induced implantation block (the Bruce effect) in mice. Anim. Reprod. Sci. 7, $377-383$.

Riches, J.H. \& Watson, R.H. (1954) The influence of the introduction of rams on the incidence of oestrus in Merino ewes. Aust. J. agric. Res. 5, 141-147.

Schinckel, P.G. (1954) The effect of the presence of the ram on the ovarian activity of the ewe. Aust. J. Agric. Res. 5, 465-469.

Shelton, M. (1980) Goats: influence of various extereceptive factors on initiation of oestrus and ovulation. Int. Goat Sheep Res. 1, 156-162.

Signoret, J.P. \& Lindsay, D.R. (1982) The male effect in domestic mammals: effect on LH secretion and ovulation--importance of olfactory cues. In Olfaction and Endocrine Regulation, pp. 63-70. Ed. W. Breiphol. IRL Press, London.

Signoret, J.P., Fulkerson, W.J. \& Lindsay, D.R. (1982) Effectiveness of testosterone treated wethers and ewes as teasers. Appl. Anim. Ethol. 9, 37-45.

Underwood, E.J., Shier, F.L. \& Davenport, N. (1944) Studies in sheep husbandry in W.A.V. The breeding season in Merino, Crossbred and British Breed ewes in the agricultural districts. J. Agric. (W.A.) II. Series 2, 135-143.

Watson, R.H. \& Radford, H.M. (1960) The influence of rams on the onset of oestrus in Merino ewes in the spring. Aust. J. Agric. Res. 11, 65-71.

Weir, B.J. (1971) The evocation of oestrus in the cuis, Galea musteloides. J. Reprod. Fert. 26, 405-408.

Received 12 February 1988 